\title{
A stable sheep cell preparation for detecting thyroglobulin auto-antibodies and its clinical applications
}

\author{
A. J. FULThORPE, I. M. ROITT, D. DONIACH, AND K. COUCHMAN \\ From the Wellcome Research Laboratory, Beckenham, Kent, the Courtauld Institute of Biochemistry, \\ and the Institute of Clinical Research, Middlesex Hospital Medical School, London
}

SYNOPSIS The preparation of stable formolized sheep cells coated with thyroglobulin and their use for the detection of auto-antibodies in human thyroiditis is described. This provides an easy laboratory test which gives results closely comparable with those using fresh tanned cells.

The agglutination titres do not closely parallel the antibody content of the serum but a good correlation may be obtained by inhibiting agglutination with thyroglobulin.

The diagnostic usefulness of the test in treating disorders of the thyroid is discussed and related to the results of tests for the other two immune systems involved in thyroiditis. The tanned red cell test may be used to differentiate Hashimoto's disease from thyroid cancer and non-toxic colloid goitre, and to assess the choice of treatment in patients with Graves' disease. It has proved of particular value in genetic studies of auto-immunity.

The detection of antibody by agglutination of tannicacid-treated red cells coated with antigen (Boyden, 1951) was first applied to the study of thyroid autoimmunity in animals by Witebsky and Rose (1956); it was shown that the serum of rabbits immunized with autologous or homologous thyroid extracts would agglutinate tanned cells coated with the thyroid antigen, often to a high titre. Following the demonstration of thyroid auto-antibodies in the serum of patients with Hashimoto's thyroiditis a number of studies have been reported in which the tanned cell method was applied to the detection of auto-antibodies in human thyroid diseases (Witebsky, Rose, Terplan, Paine, and Egan, 1957; Paine, Terplan, Rose, Witebsky, and Egan, 1957; Roitt and Doniach, 1958; Owen and Smart, 1958; Blizzard, Hamwi, Skillman, and Wheeler, 1959; Cline, Selenkow, and Brooke, 1959). The antigen responsible for the agglutination of tanned coated cells with thyroiditis sera was shown to be thyroglobulin which also gives rise to the precipitin reaction in agar gel. The tanned red cell agglutination test is of the order of 1,000 times more sensitive than the precipitin reaction, and although a positive result of low titre is not diagnostic of Hashimoto's disease, the test has proved interesting and useful in the investigation of all types of thyroid disease and theoretical problems associated with auto-immunity.

Received for publication 10 April 1961.
The preparation of fresh tanned coated cells is time-consuming and therefore inconvenient for use in the routine laboratory. This difficulty has now been overcome by treating these cells with formalin to give preparations which agglutinate specifically yet are stable for many months on storage at $4^{\circ} \mathrm{C}$. Fulthorpe (1957) previously used this technique successfully for preserving cells coated with tetanus toxoid.

\section{PREPARATION OF FORMOLIZED THYROGLOBULIN- COATED SHEEP CELLS}

REAGENTS The following were made up:-

1 Phosphate buffer $\mathrm{pH} 7 \cdot 2$ Anhyd. $\mathrm{KH}_{2} \mathrm{PO}_{4}, 12 \cdot 2 \mathrm{~g}$. anhyd. $\mathrm{Na}_{2} \mathrm{HPO}_{4}, 40 \cdot 4 \mathrm{~g}$., and $\mathrm{NaCl}, 36.0 \mathrm{~g}$. are dissolved in distilled water and made up to 5 litres.

2 Borate-succinate buffer, $0.05 \mathrm{M}, \mathrm{pH} 7.5$ Add succinic acid solution, 5.9 g./litre $\left(\mathrm{Na}_{2} \mathrm{~B}_{4} \mathrm{O}_{7} 10 \mathrm{H} 0 ; 19 \mathrm{~g}\right.$./ litre) to 3 litres of borax solution until the $p H$ is 7.5 . Nearly 3 litres is required for this. $\mathrm{NaCl}$ is added to $0.75 \%$. Add normal horse serum which has previously been heated to $56^{\circ} \mathrm{C}$. for $30 \mathrm{~min}$. to a final concentration of $1 \%$.

3 Tannic acid solution, $1: 20,000$ Tannic acid, $12 \cdot 5 \mathrm{mg}$. (Hopkin \& Williams or Merck reagent grade products were used) dissolved in $250 \mathrm{ml}$. phosphate buffer $p \mathrm{H} 7.2$ is freshly prepared before use.

4 Human thyroglobulin solution Freeze-dried thyroglobulin (prepared by the method of Derrien, Michel, 654 
and Roche, 1948), $0.5 \mathrm{~g}$., is dissolved in $250 \mathrm{ml}$. phosphate buffer $p \mathrm{H} 7 \cdot 2$.

5 Formalin (40\% formaldehyde).

\section{PREPARATION OF PRESERVED TANNED CELLS}

1 Sufficient fresh sheep cells to give a packed cell volume of $10 \mathrm{ml}$. are washed three times with physiological saline and made up to $250 \mathrm{ml}$. in phosphate buffer $p \mathrm{H} \mathrm{7.2.}$

2 The cell suspension and $250 \mathrm{ml}$. of tannic acid solution are warmed separately to $37^{\circ} \mathrm{C}$. and then combined and incubated in a water bath at $37^{\circ} \mathrm{C}$. with occasional mixing for 15 minutes.

3 The tanned cells are gently centrifuged (six minutes at 2,000 r.p.m.) and suspended in $500 \mathrm{ml}$. of phosphate buffer. The suspension is divided into two equal portions (ultimately to become the test and control cells) and the tanned cells are spun down.

4 The first batch of cells is re-suspended in $250 \mathrm{ml}$. phosphate buffer and $250 \mathrm{ml}$. of human thyroglobulin solution is added. The mixture is incubated with occasional mixing for 30 minutes at $37^{\circ} \mathrm{C}$.

5 The coated cells are gently centrifuged, washed twice with phosphate buffer, and suspended in $500 \mathrm{ml}$. of the borate-succinate buffer $p \mathrm{H} 7 \cdot 5$.

The second portion of cells is suspended in boratesuccinate buffer without coating and used for absorption of the sera before the test and as control cells in the test.

6 Both cell suspensions are stirred mechanically and $50 \mathrm{ml}$. of formalin is added to each batch slowly over a period of 20 to $30 \mathrm{~min}$. (slow addition avoids haemolysis).

7 After standing for $18 \mathrm{hr}$. at $4^{\circ} \mathrm{C}$., a further $50 \mathrm{ml}$. of formalin is added.

8 When the cells have settled and adhere to the bottom of the container, i.e., after one to three days, the supernatant is poured off and is replaced with fresh boratesuccinate buffer; the cells are re-suspended by vigorous shaking. They are again allowed to settle and washing is repeated once more.

9 Finally both batches of cells are diluted to give a $1 \%$ suspension in borate-succinate buffer; $0.2 \%$ formalin is added to the final $1 \%$ suspension as a preservative.

10 The cells are stored at 2 to $5^{\circ} \mathrm{C}$. and must be shaken very thoroughly before use to provide a uniform suspension.

\section{AGGLUTINATION TEST FOR THYROGLOBULIN AUTO-ANTIBODIES}

Heterophile antibodies are first absorbed using control uncoated cells: $0.1 \mathrm{ml}$. of patient's serum (or 3 drops delivered with a ' 30 -dropper pipette') is added to $0.4 \mathrm{ml}$. of the control cell suspension. After 10 minutes the cells are spun down and the supernatant (now a 1 in 5 dilution of serum) is serially diluted in saline. For routine testing it is convenient to make serum dilutions of 1 in 5,1 in 25 , and then 10-fold dilutions to 1 in 2.5 million with a single pipette. This procedure leads to considerable errors at high dilutions but is satisfactory for diagnostic tests; if accurate end-points are required a separate pipette must be used for each dilution.

To $0.1 \mathrm{ml}$. of each serum dilution is added $0.1 \mathrm{ml}$. of the thyroglobulin-coated test cells while $0.1 \mathrm{ml}$. of uncoated cells is added to $0.1 \mathrm{ml}$. of 1 in 5 serum dilution as a control. The cells and serum are gently mixed and allowed to stand undisturbed at room temperature for three hours or overnight before reading the results. If a batch of sera is tested together it has been found convenient to set up dilutions up to 2,500 only in the first place, leaving the next dilution without cells for one hour or until the test can just be read. If positive at 1 in 2,500 the series of dilutions is completed and cells added to them. This saves coated cells and technicians' time, particularly where the test is done routinely on all goitre patients. The test is extremely sensitive and it is essential to use a clean pipette for each serum if false weak positive results are to be avoided. The curvature at the base of the tubes may be a critical factor in affecting the stability of a positive agglutination pattern.

The most consistent results are obtained by reading the end-point as the highest dilution at which the cells settle to form a diffuse carpet over the bottom of the tube or cup. $\mathbf{A} \pm$ result appears as a smaller circle of cells having a dark outer rim, while a negative test shows as a tight button of cells (Fig. 1). The \pm results are ignored. The control cup should always be negative; if agglutination is observed the 1 in 5 serum dilution should be further absorbed using packed control cells. The dilutions and

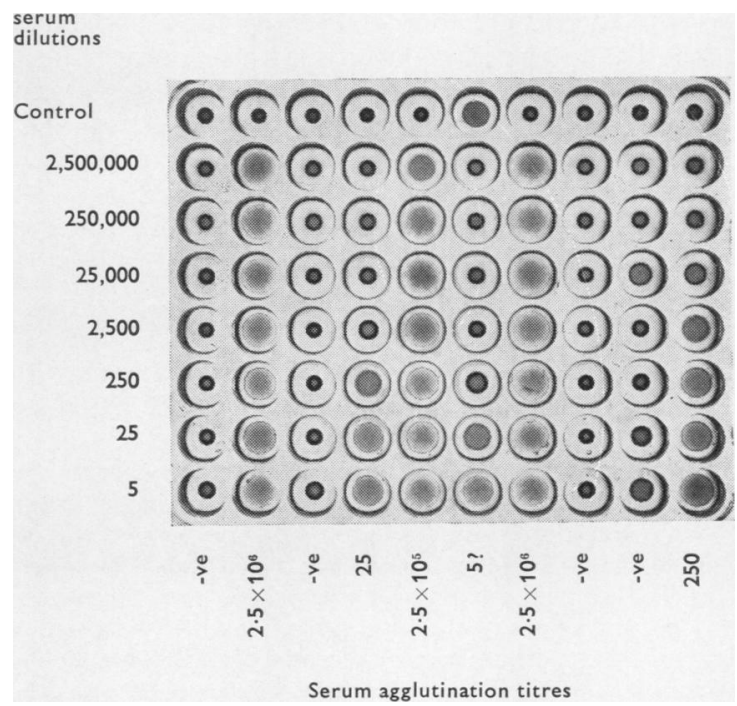

FIG. 1. Direct haemagglutination test on 10 sera in Perspex tray. Each individual serum is progressively diluted in seven cups of a vertical row, the eighth cup being set up with the 1 in 5 serum dilution and control uncoated cells. Agglutination leads to a diffuse mat of cells whereas negative sera produce a tight button of cells at the bottom of the cup. Intermediate results $( \pm)$ are regarded as negative. One of the sera shows incomplete absorption of heterophile antibodies as evidenced by a positive reaction in the control cup. 
subsequent tests are most readily carried out in Perspex agglutination trays containing $10 \times 8-1 \mathrm{ml}$. cups. ${ }^{1}$ For cleaning, the trays and pipettes are rinsed in running water and immersed in hypochlorite solution overnight (100 ml. of sodium hypochlorite, $15 \%$ available chlorine, to 1 gallon of water). They are then rinsed in hot tap water followed by distilled water. The trays are dried in air at room temperature and the pipettes in a hot drying oven.

COMPARISON OF RESULTS OBTAINED WITH FRESHLY PREPARED TANNED CELLS AND PRESERVED FORMOLIZED CELLS

Sera previously tested against freshly prepared thyroglobulin-coated cells were retitrated with a preserved cell preparation. In 88 out of 107 sera, identical results were obtained with both preparations; the preserved cells gave a titre two tubes lower with one serum, one tube lower with 13 sera, one tube higher with four sera, and two tubes higher with one serum. In view of the fact that serial dilutions with a single pipette were made on separate occasions and that \pm agglutination patterns were excluded when reading the end-point, these results show that titres obtained with the preserved cells are comparable with those previously reported in the literature using fresh unformolized cells. Different batches of preserved formolized cells gave identical results even after nine months' storage at $4^{\circ} \mathrm{C}$.

\section{RELATIONSHIP OF TANNED RED CELL TITRE TO ANTIBODY LEVEL}

The direct agglutination titre was determined on 20 sera diluted volumetrically and compared with antibody estimations made by two other methods.

1 CO-PRECIPITATION WITH RADIO-ACTIVE ANTIGEN An excess of $I^{131}$ thyroglobulin was mixed with the serum and a rabbit anti-human- $\gamma$-globulin serum added to precipitate the immune complexes (Roitt and Doniach, 1959). The radio-activity of the washed precipitate provided a measure of the antibody content of the original serum, the method being calibrated against sera having known antibody concentrations determined by the Heidelberger and Kendall (1935) quantitative precipitin technique.

2 HAEMAGGLUTINATION INHIBITION TEST WITH THYROGLOBULIN-SENSITIZED CELLS Quantities each of $0.5 \mathrm{ml}$. of a thyroglobulin solution $(2 \mu \mathrm{g} . / \mathrm{ml}$.) were dispensed in a series of $\frac{3}{8}$ in. diameter tubes, and $0.5 \mathrm{ml}$. of suitable serum dilutions added, mixed by inversion, and stood at room temperature for one hour; $0.1 \mathrm{ml}$. of sensitized cells was added to each tube and mixed as before. The end'Obtained from R. B. Turner \& Co. Ltd., 102, Church Lane, London, N.2. point was read the following day. After preliminary titration using $0.5 \mathrm{ml}$. of 10 -fold dilutions of serum, the test was repeated using two-fold dilutions over the appropriate range, i.e., between the last tube showing full agglutination and the first tube showing a clear negative. Further accuracy can be obtained using serum dilutions differing by $20 \%$. The amount of antibody contained in the calculated volume of undiluted serum which would give clear-cut agglutination when mixed with $1 \mu \mathrm{g}$. of thyroglobulin is defined as 1 milliunit of antithyroglobulin. The test is always carried out at a constant thyroglobulin level since it has been found that there is no linear relationship between the inhibiting dose of antigen and the dilution of a given serum. This is illustrated in the Table. The phenomenon has also been observed in haemagglutination inhibition tests using tetanus toxin-antitoxin mixtures (Fulthorpe, 1958).

\section{TA B LE}

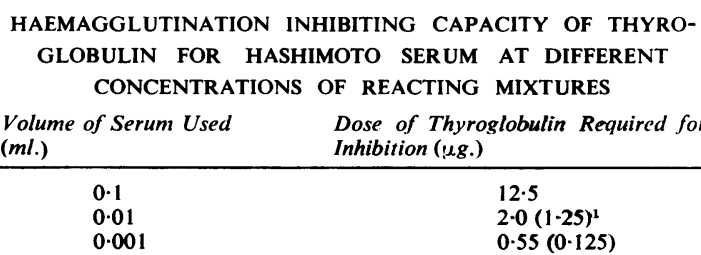

${ }^{1}$ The figures in brackets indicate the expected inhibiting dose by calculation and demonstrate the great difference in inhibiting capacity of thyroglobulin at different levels of serum concentration.

The comparative results are presented in Figs. 2A and 2B. It is apparent that antibody levels determined by the radioactive coprecipitation and quantitative precipitin methods correlate far more closely with the haemagglutination inhibition values than with the direct tanned red cell agglutination titre.

\section{CLINICAL APPLICATIONS OF THE TANNED RED CELL AGGLUTINATION TEST}

In clinical practice thyroid antibody tests are of $\rightarrow$ help in the differentiation of Hashimoto's disease (lymphadenoid goitre) from thyroid cancer and non- N toxic colloid goitres, in the diagnosis of primary myxoedema, and in the assessment of the degree of lymphadenoid changes in Graves' disease. The tests are of interest in the follow-up of patients with thyroiditis and may eventually lead to a better under- 0 standing of the pathogenesis of the disease and help $\mathbb{D}$ to elucidate its connexions with other diseases of :auto-immune aetiology.

The diagnostic usefulness and clinical applications of the tanned cell test cannot easily be dis- $\cong$ cussed without reference to the other auto-antibodies $\mathbb{D}$ present in patients with thyroid diseases, either $\mathscr{O}$ 


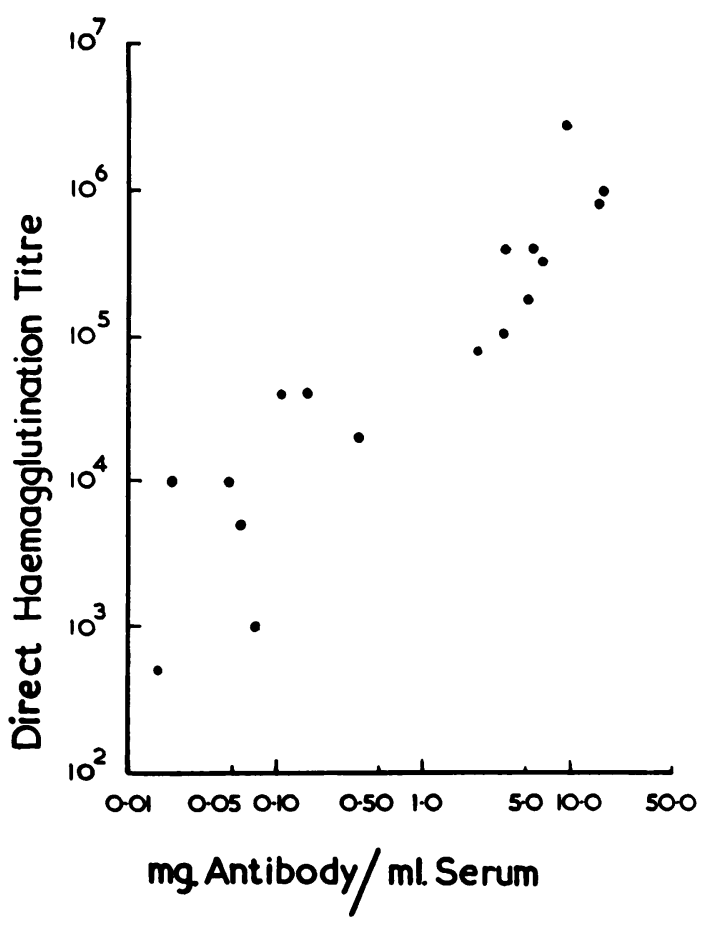

FIG. 2A. Comparison of direct agglutination titres with antibody levels determined by quantitative techniques showing rather poor correlation in these two tests.

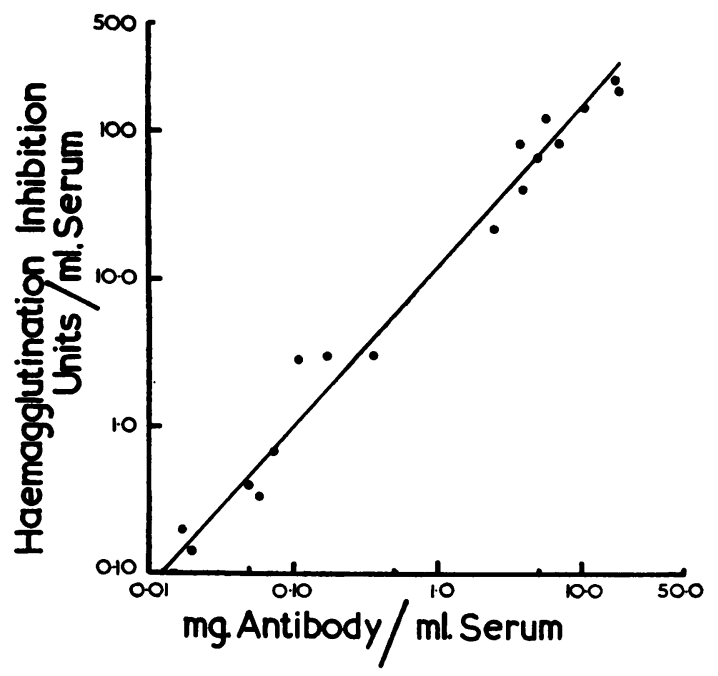

FIG. 2B. A better correlation is obtained when the quantitative antibody estimation is plotted logarithmically against the result of the haemagglutination inhibition test. The position of the line was calculated by the method of least squares. separately or in combination with anti-thyroglobulin. The most studied of these is the complement-fixing antibody against the microsomal antigen of thyroid epithelial cells (Trotter, Belyavin, and Waddams, 1957; Roitt and Doniach, 1958; Belyavin and Trotter, 1959; Anderson, Goudie and Gray, 1959). The complement-fixation test using thyrotoxic gland extracts as antigen is best carried out concurrently with the tanned red cell agglutination test for routine purposes; when the two tests are combined, one experienced technician can comfortably examine 40 sera in one day. The tanned red cell agglutination test is put up in dilutions as described above, but for the complement-fixation test the sera are first screened at 1 in 4 and 1 in 20 dilutions, in similar perspex trays. All positives are then put up again in serial dilutions from 1 in 4 to 1 in 512 against thyrotoxic thyroid and human liver to determine whether the antibodies are specific for the thyroid gland. Sera giving tanned red cell agglutination of over 2,500 are also set up in Ouchterlony gel plates for the precipitin test. Using these three tests, over $90 \%$ of Hashimoto patients and $80 \%$ of primary myxoedema cases are found to have thyroid antibodies (cf. Smart and Owen, 1960). However, owing to the extreme sensitivity of the tanned red cell agglutination test, positive results of low titre are also obtained in patients with other thyroid disorders who have a non-progressive focal thyroiditis of no clinical significance.

DIFFERENTIATION OF THYROIDITIS FROM CANCER About $30 \%$ of patients with thyroid cancer have a positive tanned red cell or complement-fixation test so that the serological reactions can only be used in conjunction with careful clinical assessment and with other tests of thyroid function. Fortunately the majority of Hashimoto patients have high titre antibodies both against thyroglobulin and the microsomal antigen whereas cancer patients give low titres and are only positive in one or other test as a rule. Fig. 3 shows the distribution of antibody titres in 303 cases of lymphadenoid goitre and in 64 cases of thyroid malignancy. Eighty-four per cent. of Hashimoto patients had tanned red cell titres of 25,000 or more with positive precipitins in two-thirds of cases, and complement-fixation titres of 64 or higher, whereas only $4.7 \%$ of cancer cases had comparable titres and only one patient showed precipitins.

The problem is more difficult when thyroiditis patients have low-titre antibodies which are of no diagnostic help. Such cases frequently have raised $\gamma$-globulins and this probably reflects the presence of other antibodies not detected by the tanned red cell or complement-fixation tests. It is therefore particularly useful to do the sero-flocculation 


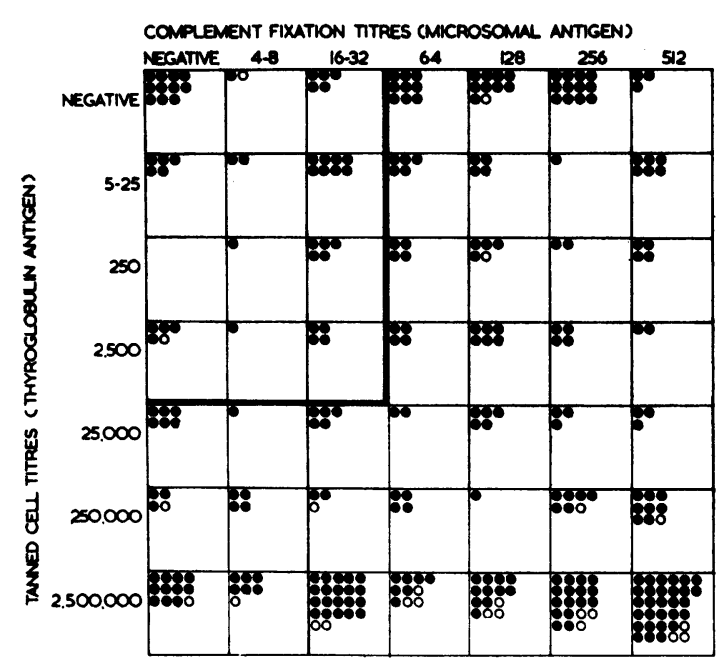

F1G. 3A. Incidence of thyroglobulin and microsomal antibodies in Hashimoto's thyroiditis. Each patient is represented by an open (male) or solid (female) circle and placed according to the serum titre obtained in each of the two tests. Eighty-four per cent. of patients had tanned red cell titre of 25,000 or over and complement-fixation titres of 64 or greater, i.e., beyond the thickened line. The majority of patients with high tanned red cell titres also gave positive precipitins in agar gel. All the 11 patients negative by the tanned red cell and complement-fixation tests were subsequently shown to have antibodies to the second antigen of the thyroid colloid (CA2) demonstrated by the fluorescent antibody technique.

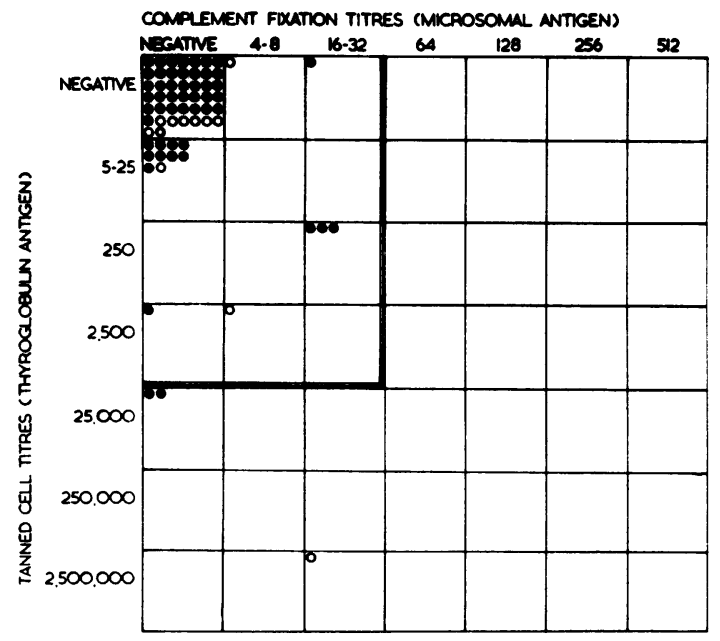

FIG. 3B. Incidence of the same two thyroid auto-antibodies in cases of thyroid cancer. Only one case had a positive precipitin test. The fluorescent antibody technique showed weak antibodies to $C A 2$ in only three of the cases negative by the tanned red cell and complement-fixation tests. reactions, especially the thymol and zinc sulphate turbidity tests. There is now concrete evidence of the existence of thyroid antibodies not detected by the tanned red cell or complement-fixation tests. Hashimoto patients with negative results in these two tests (cf. Doniach, Hudson, and Roitt, 1960) have antibodies against a second antigen of the thyroid colloid (CA2) distinct from thyroglobulin, which can only be demonstrated by Coons' fluorescent antibody technique (Balfour, Doniach, Roitt, and Couchman, 1961). The fluorescent test is also the most sensitive and specific for the microsomal (CF) antibodies which give cytoplasmic staining in frozen unfixed thyroid sections. Although the fluorescent antibody technique is perhaps too complicated and laborious to be used in routine laboratories, most Hashimoto cases can now be diagnosed by the three simpler tests since even low titre antibodies may be significant if tanned red cell and complement-fixation tests are positive together or if the patient has raised flocculation values.

DIFFERENTIATION OF THYROIDITIS FROM NON-TOXICNODULAR GOITRES With regard to distinguishing colloid non-toxic goitres from Hashimoto's disease in the absence of impaired thyroid function the tanned cell test is not diagnostic in titres under 250.000 unless precipitins are also positive. A small amount of antibody may occasionally give a high agglutination titre as can be seen in Fig. 2A. This is not necessarily associated with significant lymphoid changes in the thyroid gland. It is not known whether this implies that some patients may be immunized against thyroglobulin without having any lymphadenoid invasion of the gland. This is a possibility, since animals immunized with alum-precipitated homologous thyroglobulin usually have circulating antibodies but rarely show destructive lesions of the thyroid.

Only $3.5 \%$ of patients with colloid goitres have complement-fixing titres greater than 1 in 4 . Furthermore, patients with this disease never give positive precipitins unless there is a substantial superimposed thyroiditis in the goitre.

DIAGNOSIS OF PRIMARY MYXOEDEMA Next to Hashimoto's disease, the highest antibody levels are found in primary adult myxoedema. Twenty per cent. of cases have precipitins with tanned red cell titres of over $2 \frac{1}{2}$ million and many more have lower titres in the tanned cell test. The complement-fixation test is often positive as well. Hospital patient surveys show an incidence of $10 \%$ (Hill, 1961) up to $30 \%$ (Hackett, Beech, and Forbes, 1960; Mackay and Perry, 1960) of positive tanned red cell tests (depending upon the inclusion of patients with connective tissue 
diseases) in middle-aged women without overt thyroid disease so that the diagnostic index of the agglutination test is poor for myxoedema unless other antibodies are also present or support is obtained for the diagnosis from a low protein-bound iodine level or basal metabolic rate. However, in some cases of incipient hypothyroidism, high titre antibodies are present while the usual thyroid function tests are still boderline.

AUTO-IMMUNE THYROIDITIS ASSOCIATED WITH THYROToxicosis Thyroid antibodies are found in about two-thirds of cases of primary thyrotoxicosis, whether untreated or treated with antithyroid drugs. The great majority of patients have tanned red cell titres of 25 to 2,500 and/or complement-fixation test titre of 1 in 4 to 1 in 32 . In about $10 \%$ of thyrotoxics, especially those with severe eye signs, antibody titres are in the Hashimoto range (Hales, Myhill, Rundle, Mackay, and Perry, 1961; Doniach and Roitt, 1961). These high antibody titres reflect fairly extensive lymphadenoid lesions and such patients frequently become myxoedematous after subtotal thyroidectomy or after radio-iodine treatment. If they are given antithyroid drugs, these patients often require small maintenance doses and eventually go into prolonged remissions of their hyperthyroid symptoms. If the thyroiditis process is intense and progressive, myxoedema may supervene several years after the thyrotoxic episode, but most patients with high antibody titres probably remain euthyroid for many years (10-20). A low-grade auto-immune thyroiditis is compatible with repeated recurrences of toxicity and in such cases the antibody titres remain low compared with those of progressive thyroiditis in which antibody levels show a steady rise during the period of lymphoid replacement in the gland.

Early Hashimoto's disease may sometimes simulate mild thyrotoxicosis in that patients complain of nervousness and palpitations. These cases can be distinguished from true Graves' disease by the fact that their $I^{131}$ uptake can be suppressed with triiodothyronine (120 $\mu \mathrm{g}$. daily for 10 days) and also because they fail to improve when given antithyroid drugs. The tanned red cell test may be completely negative and only complement-fixing antibodies, sometimes to high titres, and anti-CA2 are present. It may be that acinar destruction due to as yet unknown factors releases metabolically active iodinated proteins which remain in the circulation in the absence of antibodies to remove and inactivate them (Roitt and Doniach, 1960).

EFFECT OF TREATMENT ON ANTIBODY LEVELS After operation for Hashimoto goitre, the precipitin level decreases sharply but the tanned red cell test remains positive for many years after thyroidectomy owing to its great sensitivity. In Hashimoto patients treated with thyroid hormone, precipitins remain positive for some years and the tanned red cell test remains of high titre even after the goitre has gone down completely. Complement-fixation titres usually decrease in treated patients.

In thyrotoxic patients with focal thyroiditis, $\mathrm{I}^{\mathbf{1 3 1}}$ treatment may lead to an increase in the complementfixation antibody level, possibly as a result of increased antigen release, though the tanned red cell titre appears to remain unchanged. In wellestablished primary myxoedema, antibody levels do not change with replacement therapy (Owen and Smart, 1958); this does not necessarily apply to the early phase of atrophic thyroiditis.

To summarize, it is safest to rely on the precipitin test when Hashimoto's disease has to be distinguished from thyroid cancer, but even this requires the support of radioiodine topographical studies as well as careful clinical assessment of each individual case. A positive precipitin test indicates widespread thyroiditis even in patients with underlying thyrotoxicosis but this occurs in less than $1 \%$ of cases. In patients with negative precipitins, a high tanned red cell titre, together with a high complementfixation titre, is strongly indicative of lymphadenoid goitre, whether the patient is euthyroid or hyperthyroid. Low titres or even completely negative results in both tests do not rule out Hashimoto's disease but additional help may be obtained from the thymol and zinc sulphate turbidity tests and from the fluorescent test for antibodies to the second antigen of the thyroid colloid. Needle biopsy is advisable in difficult cases.

Thyrotoxic patients with antibodies may be treated medically for a trial period while the trend of their antibody titre is established. If titres are low and remain stationary, operation is unlikely to cause myxoedema but if the titres are found to rise progressively it is preferable to avoid surgery or radio-iodine treatment unless cardiac involvement renders a rapid cure imperative.

We are grateful to Professor F. Dickens, Professor Sir Charles Dodds, and Mr. R. Vaughan Hudson for their interest and constant support in this work, and to Professor A. Kekwick and the Clinical Research Committee for facilities afforded in the Institute of Clinical Research.

We wish to thank the pathologists, surgeons, and physicians from the Middlesex Hospital and many other hospitals who kindly sent us serum from their patients for thyroid antibody tests. Without their help we could not have gathered the material on which this work was based. 
Support was provided by the Mary Kinross Charitable Fund and also by a grant to the Medical School from the British Empire Cancer Campaign Fund.

\section{REFERENCES}

Anderson, J. R., Goudie, R. B., and Gray, K. G. (1959). Scot. med. J., 4,64 .

Balfour, B. M., Doniach, D., Roitt, I. M., and Couchman, K. (1961). Brit. J. exp. Path., 42, 307.

Belyavin, G., and Trotter, W. R. (1959). Lancet, 1, 648.

Blizzard, R. M., Hamwi, G. J., Skillman, T. G., and Wheeler, W. E. (1959). New Engl. J. Med., 260, 112.

Boyden, S. V. (1951). J. exp. Med., 93, 107.

Cline, M. J., Selenkow, H. A., and Brooke, M. S. (1959). New Engl. J. Med., 260, 117.

Derrien, Y., Michel, R., and Roche, J. (1948). Biochim. Biophys. Acta, $2,454$.

Doniach, D., Hudson, R. V., and Roitt, I. M. (1960). Brit. med. J., 1, 365 .

-, and Roitt, I. M. (1961). In Gardner Hill ed. Modern Trends in Endocrinology, p. 278. Butterworth, London.
Fulthorpe, A. J. (1957). J. Hyg. (Lond.), 55, 382.

(1958). Immunology, 1, 365.

Hackett, E., Beech, M., and Forbes, I. J. (1960). Lancet, 2, 402.

Hales, I. B., Myhill, J., Rundle, F. F., Mackay, I. R., and Perry, B. (1961). Ibid, 1, 468.

Heidelberger, M., and Kendall, F. E. (1935). J. exp. Med., 61, 559.

Hill, O. (1961). Brit. med. J., 1, 1793.

Mackay, I. R., and Perry, B. T. (1960). Aust. Ann. Med., 9, 84.

Owen, S. G. and Smart, G. A. (1958). Lancet, 2, 1034.

Paine, J. R., Terplan, K., Rose, N. R., Witebsky, E., and Egan, R. W. (1957). Surgery, 42, 799.

Roitt, I. M., and Doniach, D. (1958). Lancet, 2, 1027.

- (1959). In Shaffer, J. H., Logrippo, G. A., and Chase, M. E. ed. Mechanisms of Hypersensitivity, p. 325. (Henry Ford Hospital International Symposium.) Little, Brown \& Co., Boston.

,-- (1960). Brit. med. Bull., 16, 152.

Smart, G. A., and Owen, S. G. (1960). Postgrad. med. J., 36, 442.

Trotter, W. R., Belyavin, G., and Waddams, A. (1957). Proc. roy. Soc. Med., 50, 961.

Witebsky, E., and Rose, N. R. (1956). J. Immunol., 76, 408.

- - Terplan, K., Paine, J. R., and Egan, R. W. (1957). J. Amer. med. Ass., 164, 1439. 